\title{
De herplaatsingsplicht in de praktijk
}

\author{
mr. dr. Pascal Kruit en mr. Jacobien Sap*
}

\section{Inleiding}

Door de invoering van de Wwz heeft de herplaatsingsplicht aanzienlijk aan belang gewonnen. Door de verankering van deze verplichting in artikel 7:669 lid $1 \mathrm{BW}$ is het onderzoeken van herplaatsingsmogelijkheden een constitutieve voorwaarde geworden voor ieder ontslag, met uitzondering van het ontslag wegens verwijtbaar handelen (de e-grond) en situaties waarin dit in redelijkheid niet van de werkgever kan worden gevergd. Van een werkgever wordt verwacht dat hij onderzoekt of herplaatsing in een passende functie binnen een redelijke termijn, al dan niet met behulp van scholing, mogelijk is. De herplaatsingsplicht strekt zich uit over de gehele groep waartoe de werkgever behoort. Deze verregaande verplichting tot herplaatsing alvorens tot het ontslag over te gaan roept in de praktijk vele vragen op. In dit artikel bespreken wij een aantal van die voor de praktijk belangrijke vragen. Nadat in $\S 2$ het wettelijk kader als uitgangspunt kort wordt geschetst, wordt in $\S 3$ de reikwijdte van het begrip 'passende functie' vastgesteld. In $\S 4$ staat de scholingsplicht centraal, waarna in $\S 5$ de herplaatsing in concernverband wordt besproken. In $\S 6$ wordt afgesloten met een korte conclusie.

\section{Het wettelijk kader}

De herplaatsingsplicht werd met de invoering van de Wwz gecodificeerd in artikel 7:669 lid $1 \mathrm{BW}$. Hierin staat thans:

'De werkgever kan de arbeidsovereenkomst opzeggen indien daar een redelijke grond voor is en herplaatsing van de werknemer binnen een redelijke termijn, al dan niet met behulp van scholing, in een andere passende functie niet mogelijk is of niet in de rede ligt. Herplaatsing ligt in ieder geval niet in de rede indien sprake is van verwijtbaar handelen of nalaten van de werknemer als bedoeld in lid 3 , onderdeel e.'

De wetgever heeft bij de invoering van de Wwz duidelijk aangegeven dat geen wijziging werd beoogd van hetgeen destijds in het Ontslagbesluit en de daarop gebaseerde Beleidsregels Ontslagtaak UWV omtrent her-

Pascal Kruit en Jacobien Sap zijn beiden advocaat bij Boontje Advocaten. plaatsing was geregeld. ${ }^{1}$ Hoewel het Ontslagbesluit geen algemene herplaatsingsplicht voor iedere ontslagsituatie kende - alleen bij langdurige arbeidsongeschiktheid was deze expliciet neergelegd in artikel 5:2 - gaf het UWV in zijn Beleidsregels wel invulling aan een in meer algemene zin van toepassing zijnde herplaatsingsverplichting. ${ }^{2}$ Het UWV toetste in iedere ontslagaanvraag conform zijn eigen Beleidsregels of de werkgever herplaatsing van de voor ontslag aangedragen werknemer voldoende had onderzocht. ${ }^{3}$ Een nadere concretisering werd echter in de Beleidsregels niet gegeven en omdat de beslissing van het UWV niet voor bezwaar of beroep vatbaar was, bleek herplaatsing in de praktijk geen bijster grote rol te spelen. In de ontbindingsprocedure ex artikel 7:685 BW (oud) was helemaal geen plaats ingeruimd voor de herplaatsingsplicht, maar kon de kantonrechter - indien hij hiervoor aanleiding zag - de mogelijkheid tot herplaatsing betrekken in de vraag of er sprake was van een zodanige verandering in de omstandigheden dat de arbeidsovereenkomst op korte termijn diende te eindigen. In het voor de werknemer meest gunstige geval werd de mogelijkheid tot herplaatsing betrokken in de door de rechter te maken belangenafweging. Van een harde eis om herplaatsing te onderzoeken alvorens een ontbindingsverzoek kon worden toegewezen was echter geen sprake.

In het ontslagrecht onder de Wwz is de herplaatsingsverplichting als harde voorwaarde voor (vrijwel ieder) ontslag neergelegd. Daar waar voor invoering van de Wwz de mogelijkheid tot herplaatsing kon worden meegewogen in de afweging of ontslag redelijk was, kan thans niet tot ontslag worden overgegaan wanneer herplaatsing mogelijk is. Dit brengt met zich dat minder makkelijk aan de herplaatsingsplicht kan worden voorbijgegaan. Wij hebben daarom - zoals eerder al door andere auteurs werd geschreven - sterke twijfels bij de uitlating van de minister dat de herplaatsingsplicht met invoering van de Wwz niet is verzwaard. ${ }^{4}$ Dit (b)lijkt namelijk wel het geval te zijn.

In deze paragraaf zullen we nader verkennen welke inkleuring het wettelijk kader aan de herplaatsingsplicht geeft. Hierbij zullen zowel de uit de wet voortvloeiende

\footnotetext{
Kamerstukken II 2013/14, 33818, 3, p. 98.

Beleidsregels Ontslagtaak UWV, hfst. 20, par. 1, 2015.

Zie hierover: L.B. de Graaf, 'Herplaatsing: waar is de redelijkheid gebleven?' TRA 2016/82

4. Zie o.a. L.B. de Graaf, 'Herplaatsing: waar is de redelijkheid gebleven?' TRA 2016/82; F.G. Laagland en I. Lintsen, 'Werkgeverschap in concernverhoudingen', TRA 2016/13; R. Olivier en J.P. Wiewel, 'Herplaatsing binnen de groep', TAP 2017/2, p. 4-10 en R.M. Beltzer en S. Schmeetz, 'Herplaatsing binnen het concern', TVO 2017/2, p. 64-74.
} 
voorwaarden als het 'niet in de rede liggen' van herplaatsing worden beschouwd.

\subsection{Wat zijn de vereisten om te voldoen aan de} herplaatsingsplicht?

Uit de tekst van artikel 7:669 BW blijkt dat sprake is van een inspanningsplicht, niet van een prestatieplicht. Dit valt af te leiden uit het feit dat opzegging kan geschieden indien herplaatsing niet mogelijk blijkt te zijn. Het is voor een werkgever dus niet verplicht om de werknemer ook daadwerkelijk ergens te herplaatsen, zolang de werkgever kan aantonen dat hij zich voldoende heeft ingespannen om de werknemer te herplaatsen en daarmee ontslag te voorkomen.

Welke stappen moeten worden genomen, alvorens is voldaan aan deze herplaatsingsinspanning? Uit de hiervoor geciteerde wettelijke bepaling volgt dat voor het voldoen aan de herplaatsingsplicht een drietal vragen moet worden beantwoord:

1. Is er een passende functie beschikbaar?

2. Kan een passende functie door middel van scholing beschikbaar komen?

3. Komt de passende functie binnen een redelijke termijn beschikbaar?

In artikel 7:669 lid $5 \mathrm{BW}$ staat vervolgens dat nadere regels zullen worden vastgesteld met betrekking tot herplaatsing van werknemers. Deze nadere regels zijn vervat in artikel 9 en 10 Ontslagregeling. ${ }^{5}$ Artikel 9 Ontslagregeling ziet hierbij op de vraag wanneer een functie als 'passend' kwalificeert en artikel 10 geeft invulling aan hetgeen moet worden verstaan onder de 'redelijke termijn'.

De passende functie heeft krachtens artikel 9 Ontslagregeling vier voorwaarden:

- de passende functie ziet op zowel openstaande vacatures als reeds bezette arbeidsplaatsen door bijvoorbeeld tijdelijke werkkrachten of zelfstandigen;

- het dient te gaan om een functie of vacature die aansluit bij de werknemer op basis van zijn opleiding, ervaring en capaciteiten, al dan niet met behulp van scholing;

- de passende functie moeten binnen een redelijke termijn kunnen worden vervuld; en

- de passende functie dient voorts te worden gezocht binnen de groep waartoe de onderneming behoort.

De nadere invulling van de passende functie zal in $\S 3$ aan de orde komen. De reikwijdte van de scholingsplicht wordt besproken in $\$ 4$ en de herplaatsing binnen concernverband wordt nader uitgewerkt in $\S 5$.

De redelijke termijn waarbinnen herplaatsing al dan niet plaats dient te vinden, is gelijkgesteld aan de wettelijke opzegtermijn die voor een werknemer in acht dient te worden genomen. Dit betreft één tot vier maanden, afhankelijk van de lengte van het dienstverband. Een eventueel in een cao of arbeidsovereenkomst overeenge-

5. Ontslagregeling, Stcrt. 2015, 12685. komen afwijkende opzegtermijn wordt buiten beschouwing gelaten, nu expliciet wordt verwezen naar de opzegtermijn die voortvloeit uit artikel 7:672 lid 2 en 3 BW. Vanuit de beschermingsgedachte die aan het arbeidsrecht ten grondslag ligt, is voor arbeidsgehandicapten een langere herplaatsingstermijn van 26 weken opgenomen, ongeacht de duur van het dienstverband. ${ }^{6}$

2.2 Wanneer ligt herplaatsing niet in de rede? Herplaatsing hoeft niet te geschieden wanneer dit niet mogelijk is of omdat herplaatsing niet in de rede ligt, aldus de wettekst van artikel 7:669 lid 1 BW. Herplaatsing kan bijvoorbeeld niet mogelijk zijn, omdat geen passende functies voor de werknemer beschikbaar zijn/ komen, maar wanneer ligt herplaatsing dan niet in de rede?

De Ontslagregeling geeft geen uitwerking aan situaties waarin herplaatsing niet in de rede ligt. De laatste volzin van artikel 7:669 lid 1 BW zegt hierover dat herplaatsing in ieder geval niet in de rede ligt wanneer de werknemer zich zodanig verwijtbaar heeft gedragen dat de arbeidsovereenkomst op de e-grond wordt ontbonden. ${ }^{7}$ Tevens ligt herplaatsing niet in de rede wanneer sprake is van detentie of illegaliteit van de werknemer, getuige de nota naar aanleiding van het verslag. ${ }^{8}$ De Graaf meent dat herplaatsing in zulke gevallen geheel niet aan de orde komt, en dat 'niet in de rede liggen' derhalve niet als uitzondering kan gelden wanneer herplaatsing wel mogelijk zou zijn. ${ }^{9}$ Dit lijkt ons een te verstrekkende conclusie, nu herplaatsing conform de wet als harde voorwaarde bij ieder ontslag moet worden getoetst.

In de rechtspraak komt de vraag wanneer herplaatsing niet in de rede ligt maar mondjesmaat naar voren. De Kantonrechter Rotterdam stelde dat het enkel aanvoeren dat geen enkele vacature als passend kan worden aangemerkt, onvoldoende is om te onderbouwen dat herplaatsing niet in de rede ligt. ${ }^{10}$ Niet in de rede liggen ziet dus op meer dan enkel de afwezigheid van passende vacatures. Zo oordeelde Kantonrechter Arnhem dat het niet in de rede ligt om een disfunctionerende werknemer te herplaatsen wanneer de werkgever van mening is dat de werknemer bepaalde kerncompetenties mist die benodigd zijn voor de invulling van de openstaande vacatures bij de werkgever. ${ }^{11}$ Kantonrechter Rotterdam oordeelde dat in de situatie dat de werknemer zich schuldig maakt aan strafbare handelingen in de privétijd, zoals drugsbezit, herplaatsing eveneens niet in de rede ligt. ${ }^{12}$

Olivier en Wiewel stellen terecht dat de bewoording van artikel 7:669 lid 1 BW tekstueel niet uitsluit dat het ook

\footnotetext{
Kamerstukken II 2013/14, 33818, 3, p. 45.

Kamerstukken I/ 2013/14, 33818, 39.

Kamerstukken I/ 2013/14, 33818, 7, p. 85-86.

L.B. de Graaf, 'Herplaatsing: waar is de redelijkheid gebleven?' TRA 2016/82.

10. Ktr. Rotterdam 17 januari 2018, ECLI:NL:RBROT:2018:281.

11. Ktr. Arnhem 19 december 2016, ECLI:NL:RBGEL:2016:7119.

12. Ktr. Rotterdam 9 januari 2018, ECLI:NL:RBROT:2018:454.
} 
situaties kan betreffen waarbij herplaatsing wel mogelijk is, maar dat er een andere reden is waarom herplaatsing van de werknemer niet van de werkgever gevergd kan worden. ${ }^{13}$ Dit wordt ook bevestigd in de rechtspraak. Wanneer sprake is van een ernstig en duurzaam verstoorde arbeidsverhouding, kan dit ertoe leiden dat herplaatsing niet in de rede ligt. ${ }^{14}$ Zo oordeelde de Hoge Raad recentelijk dat wanneer de werkgever al meermaals de werkomstandigheden heeft aangepast, er sprake is van een ernstige en duurzame verstoring van de arbeidsverhouding in zowel de samenwerking met collega's als met de leidinggevenden en de directie, en de werkgever het vertrouwen in de werknemer definitief is verloren, het niet meer in de rede ligt dat de werkgever over gaat tot herplaatsing van de werknemer. ${ }^{15}$ Dit ondanks dat de werknemer hier wellicht geen verwijt viel te maken. Dat herplaatsing in geval van een verstoorde arbeidsverhouding niet in de rede ligt, zal binnen een klein bedrijf sneller worden aangenomen. Rechters kennen, naar blijkt uit verschillende uitspraken, waarde toe aan de beperkte omvang van de organisatie. ${ }^{16}$

\section{Passende functie}

In het kader van de herplaatsingsplicht dient een tweetal perspectieven van elkaar te worden onderscheiden: (i) wanneer kan van een werkgever worden verlangd een beschikbare functie als zijnde 'passend' aan te bieden en

(ii) wanneer mag een werknemer een aan hem aangeboden passende functie weigeren? De in de wet en Ontslagregeling neergelegde herplaatsingsverplichting ziet enkel op de verplichting die op de werkgever rust om een passende functie aan te bieden en geeft geen kaders ten aanzien van hetgeen van een werknemer kan worden gevergd in het kader van het aanvaarden van een aangeboden passende functie. Wij trekken deze twee perspectieven daarom uit elkaar en behandelen deze in het navolgende afzonderlijk. Tot slot bespreken wij in deze paragraaf hoe moet worden omgegaan met de situatie waarin meerdere passende functies beschikbaar zijn en werkgever en werknemer een andere voorkeur hebben.

\subsection{Werkgeversperspectief}

Bij het zoeken naar een passende functie is voor de werkgever een actieve rol weggelegd. De werkgever kan niet volstaan met het wijzen op vacatures of het aanbieden van hulp bij solliciteren. Hij dient de werknemer te begeleiden, een initiërende rol aan te nemen en eventuele belemmeringen voor een passende functie weg te nemen. ${ }^{17}$

14. Hof Den Bosch 25 januari 2018, ECLI:NL:GHSHE:2018:254

15. HR 16 februari 2018, ECLI:NL:HR:2018:220.

16. Ktr. Alkmaar 18 december 2015, ECLI:NL:RBNHO:2015:11461; Ktr. Rotterdam 16 oktober 2015, ECLI:NL:RBROT:2015:7564; Ktr. Breda 15 november 2015, ECLI:NL:RBZWB:2015:8520.

17. Ktr. Rotterdam 1 juni 2016, ECLI:NL:RBROT:2016:4136.

\subsubsection{Wat wordt verstaan onder ervaring, opleiding en capaciteiten?}

Het begrip 'passende functie' wordt gedefinieerd in artikel 9 lid 3 Ontslagregeling: 'Van een passende functie is sprake wanneer deze aansluit bij de opleiding, ervaring en capaciteiten van de werknemer.' Een werkgever dient bij het zoeken naar een passende functie rekening te houden met de ervaring, opleiding en capaciteiten van de werknemer. In de toelichting bij dit artikel staat dat het moet gaan om functies die aansluiten bij het niveau van de werkzaamheden die de werknemer op dat moment verricht, maar dat ook breder moet worden gekeken. ${ }^{18} \mathrm{Er}$ moet tevens rekening worden gehouden met ervaring die werknemer in eerdere functies heeft opgedaan, evenals met de kennis die de werknemer in de door hem genoten opleidingen heeft vergaard. Van een werkgever wordt aldus verwacht dat op persoonsniveau wordt onderzocht of een passende functie binnen de organisatie voorhanden is. Het functieniveau dat de werknemer heeft, is daarbij niet bepalend. Sterker nog, in de definitie van het begrip 'passende functie' komt het functieniveau niet terug. De werkgever zal zowel boven als onder het functieniveau van de werknemer moeten zoeken naar passende functies.

Het aanbieden van een functie boven het niveau van de werknemer is moeilijk. In de rechtspraak wordt ook expliciet benoemd dat van werkgevers niet kan worden verlangd dat zij hun werknemers boven hun sterkte aannemen, ook niet bij wijze van schadevergoeding in natura. ${ }^{19}$

Andersom is de vraag moeilijker te beantwoorden. Wat te doen als een werknemer die tegenwoordig in een managementfunctie werkzaam is, ervaring heeft in een secretaressefunctie? Een werknemer kan in de start van zijn loopbaan hebben gewerkt als secretaresse of hiervoor in het verleden een opleiding hebben gevolgd. Anders gezegd: is een functie die (ver) beneden het niveau van de oorspronkelijke functie ligt, aan te merken als een passende functie wanneer de werknemer in het verleden ervaring heeft met werkzaamheden in deze functie, en dient de werkgever deze functie dan ook aan te bieden? Wij menen dat dit in beginsel wel het geval is. Wanneer de werknemer beschikt over de capaciteiten om de betreffende lagere functie te vervullen, kwalificeert die functie daarmee als passend en zal de werkgever tot het aanbieden hiervan moeten overgaan.

In de rechtspraak is met name de vraag naar herplaatsing in een (veel) lagere functie aan de orde geweest. Deze rechtspraak bevestigt dat een functie op een lager niveau dan de oorspronkelijke functie kan worden aangemerkt als passend, maar dat het vervolgens niet altijd in de rede ligt om deze functie aan de werknemer aan te bieden, dan wel dat van een werknemer niet kan worden gevergd de aangeboden functie te accepteren. Hierbij is het volgens de Kantonrechter Assen wel van belang dat

18. Stcrt. 2015,12685

19. Ktr. Amsterdam 29 april 2016, zaaknummer KK 16-515, JIN 2016/166. 
werkgever en werknemer met elkaar overleggen, om zo rekening te houden met de belangen van de werknemer. ${ }^{20}$ Zonder dit overleg kan een lichtere functie niet zonder meer als niet passend worden aangemerkt, of worden gesteld dat het aanbieden van die functie niet in de rede ligt.

Wanneer een werknemer in een hogere functie werkzaam is, zoals die van directeur van een onderneming, ligt herplaatsing in een lagere functie minder snel in de rede. Zo werd in verschillende uitspraken over het ontslag van een (statutair) bestuurder geoordeeld dat herplaatsing niet in de rede lag, nu het in praktijk niet voor de hand ligt dat een bestuurder een functie zal bekleden waaraan hij voorheen nog leiding gaf. ${ }^{21}$ Ook Kantonrechter Leeuwarden oordeelde dat een functie als groepsleerkracht wel kon worden aangemerkt als passende functie voor een schooldirecteur, nu deze functie aansloot bij zijn jarenlange ervaring als leerkracht. ${ }^{22}$

\subsection{Werknemersperspectief}

Een werknemer die op het punt staat ontslagen te worden, zal doorgaans graag herplaatst willen worden in een soortgelijke functie. Maar wat als deze niet voorhanden is, maar wel een aantal andere functies tegen (veel) lager salaris en/of een grotere reisafstand wordt aangeboden? Kan een werknemer functies afwijzen, bijvoorbeeld omdat het salaris of de reisafstand hem niet aanstaan, of moet hij hier een goede grond voor hebben? In deze paragraaf zal op deze vragen worden ingegaan.

\subsubsection{Is teruggang in salaris een reden om een passende functie te meigeren?}

In het huidige ontslagrecht is loon in principe niet meer van belang bij de bepaling of een functie al dan niet passend wordt bevonden (daar waar dit volgens de Beleidsregels onder het oude recht wel een relevant criterium was $\left.^{23}\right)$. Dit brengt met zich dat een aangeboden passende functie mogelijk op een sterk lager salarisniveau ligt dan de huidige functie van de werknemer. Kan de werknemer in dat geval besluiten de aangeboden passende functie af te wijzen?

$\mathrm{Nu}$ de hoogte van het salaris bij de uitwerking van het begrip passende functie geen rol speelt, moet voor de vraag of een aangeboden passende functie dient te worden aanvaard, worden gekeken naar de gevolgen van het weigeren van een passende functie. Hiermee bedoelen wij dat wanneer een werknemer een aangeboden passende functie afwijst en de werkgever vervolgens succesvol tot ontslag overgaat, getoetst dient te worden of de werknemer in zijn recht stond om de aangeboden passende functie af te wijzen, of dat de afwijzing betekent dat de werknemer verwijtbaar werkloos wordt. In dat verband is relevant het bepaalde in artikel 24 lid 1 en 3

20. Ktr. Assen 15 augustus 2017, ECLI:NL:RBNNE:2017:3140.

21. Zie onder andere: ECLI:NL:RBAMS:2015:8600; ECLI:NL:RBDHA: 2016:4882; ECLI:NL:RBNHO:2016:5666; ECLI:NL:GHARL:2016:10230; ECLI:NL:RBLIM:2016:8114; ECLI:NL:RBGEL:2016:6853.

22. Ktr. Leeuwarden 22 juli 2015, ECLI:NL:RBNNE:2015:3611.

23. Beleidsregels Ontslagtaak UWV, p. 20-3.
WW, waarin is bepaald dat de werknemer passende arbeid moet aanvaarden om te voorkomen dat hij verwijtbaar werkloos wordt. In artikel 24 lid $3 \mathrm{WW}$ staat het volgende:

'Als passende arbeid, bedoeld in het eerste lid, wordt beschouwd alle arbeid die voor de krachten en bekwaamheden van de werknemer is berekend, tenzij aanvaarding om redenen van lichamelijke, geestelijke of sociale aard niet van hem kan worden gevergd. $(\ldots)^{\prime}$

De uitwerking van dit begrip passende arbeid is vastgelegd in het Besluit passende arbeid WW en $\mathrm{ZW} .{ }^{24}$ In artikel 4 lid 1 Besluit passende arbeid WW en ZW staat dat in de eerste zes maanden waarin de werknemer recht heeft op een uitkering op grond van de WW of de ZW, arbeid als passend wordt aangemerkt wanneer onder andere met de arbeid een bedrag wordt verdiend ter hoogte van ten minste $70 \%$ van het inkomen, genoten in de dienstbetrekking waaruit de werknemer werkloos of ziek is geworden. De nota van toelichting bij dit besluit vermeldt dat de verplichting om passende arbeid te aanvaarden ook geldt wanneer het voor de werknemer duidelijk is dat werkloosheid dreigt. ${ }^{25}$ De werknemer dient dus te voorkomen dat hij werkloos wordt wanneer hij daartoe de mogelijkheid heeft. Dit betekent dat de werknemer passende arbeid zoals omschreven in het besluit zal moeten accepteren. Vanuit uitkeringsperspectief brengt het voorgaande mee dat de werknemer alle aangeboden passende functies met een salaris vanaf $70 \%$ van het laatstverdiende loon als passende functie moet accepteren, zulks op straffe van het verlies van zijn uitkering.

De weigering van een aangeboden passende functie levert echter niet per definitie ernstig verwijtbaar gedrag op. Zo meende Kantonrechter Enschede dat een werknemer stevig mocht aarzelen over de vraag of hij een aangeboden functie wel moest aanvaarden, toen bleek dat deze functie een aanzienlijk lager salaris had en de functie grotendeels in het buitenland diende te worden uitgevoerd. ${ }^{26}$ Het weigeren van de functie werd derhalve niet als ernstig verwijtbaar gedrag aangemerkt. Toch kan het weigeren van een passende functie zonder gegronde reden wel verwijtbaar handelen van de werknemer opleveren. ${ }^{27}$ De werknemer zal wel zijn recht op transitievergoeding behouden. De weigering van de aangeboden functie zou anderzijds wel kunnen resulteren in een (gedeeltelijk) verlies van de WW-uitkering, nu de werknemer verwijtbaar werkloos wordt. De stap naar 'ernstig verwijtbaar handelen' zal naar onze mening echter niet snel gemaakt kunnen worden.

24. Besluit van 11 december 2014, houdende nadere regels omtrent het begrip passende arbeid zoals genoemd in de artikelen 24, derde lid, van de Werkloosheidswet en 30, vijfde lid, van de Ziektewet (Besluit passende arbeid WW en ZW), Stb. 2014, 525.

25. Nota van toelichting bij Besluit passende arbeid WW en ZW, Stb.2014, 525.

26. Ktr. Enschede 12 februari 2018, ECLI:NL:RBOVE:2018:518.

27. Ktr. Leeuwarden 22 juli 2015, ECLI:NL:RBNNE:2015:3611. 


\subsubsection{Hoeveel mag de reistijd voor een passende functie bedragen?}

In de definitie van een passende functie komt het element 'reisafstand' niet voor. Een werkgever mag aldus niet verzuimen een passende functie aan te bieden met een beroep op een lange reisafstand.

Wanneer een werkgever meerdere vestigingen heeft, kan de situatie ontstaan dat een werknemer herplaatst kan worden bij een andere vestiging dan die waar oorspronkelijk werd gewerkt, met als gevolg een enorme toename van de reistijd. Wanneer de afstand woon-werkverkeer met een andere vestiging te groot wordt, lijkt het voor een werknemer niet altijd redelijk om een passende functie te moeten accepteren. Wat kan in dit kader in redelijkheid van een werknemer worden gevergd?

De Ontslagregeling heeft reistijd niet nader geconcretiseerd. Daarom dient onzes inziens aansluiting te worden gezocht bij de reistijd zoals omschreven in het Besluit passende arbeid WW en ZW. ${ }^{28}$ Op grond van artikel 24 lid $3 \mathrm{WW}$ moet een werknemer bereid zijn passende arbeid te aanvaarden. Een werknemer kan naar onze mening daarom worden verplicht een passende functie te aanvaarden, zolang de reistijd binnen de grenzen van artikel 24 lid $3 \mathrm{WW}$ en het hieraan verbonden Besluit passende arbeid WW en ZW valt.

Artikel 4 Besluit passende arbeid WW en ZW bepaalt dat een functie waarvoor de werknemer meer dan twee uur per dag moet reizen, gedurende de eerste zes maanden niet passend is. Hiermee wordt voorkomen dat iemand wordt gedwongen om een baan te accepteren waarvoor een langere reistijd nodig is, of dat hij moet verhuizen voor zijn werk. ${ }^{29} \mathrm{Na}$ zes maanden zal een langere reistijd geen belemmering meer vormen om functies aan te merken als passende arbeid, aldus het Besluit passende arbeid WW en ZW. Hieraan wordt vervolgens geen maximumduur meer gekoppeld.

$\mathrm{Nu}$ de redelijke termijn voor herplaatsing maximaal zes maanden is, menen wij dat aansluiting kan worden gezocht bij de maximale reistijd van een uur enkele reis, als bedoeld in voornoemd Besluit. Wij merken hierbij op dat het 'kale reistijd' betreft, dus zonder rekening te houden met (dagelijkse) files. De daadwerkelijke reistijd kan aldus in de praktijk beduidend langer zijn dan een uur enkele reis. ${ }^{30}$

\subsection{Wie kiest bij meerdere passende functies?}

De situatie kan ontstaan dat een werkgever meerdere passende functies heeft om een werknemer te herplaatsen. Mag de werkgever kiezen welke passende functie

28. Besluit van 11 december 2014, houdende nadere regels omtrent het begrip passende arbeid zoals genoemd in de artikelen 24, derde lid, van de Werkloosheidswet en 30, vijfde lid, van de Ziektewet (Besluit passende arbeid WW en ZW), Stb. 2014, 525.

29. Nota van toelichting bij Besluit passende arbeid WW en ZW, Stb.2014, 525.

30. Volgens Kantonrechter Zutphen staan werknemers ook in hun recht om een passende functie te weigeren indien dit hen een reistijd van bijna vier uur per dag oplevert (Ktr. Zutphen 7 juni 2017, ECLI:NL:RBGEL: 2017:4252). hij aan de werknemer aanbiedt, mag de werknemer kiezen in welke functie hij herplaatst wil worden, of bestaat er zoiets als 'de meest passende functie' die op dat moment moet worden aangeboden? Deze situatie is niet wettelijk geregeld en (de toelichting op) de Ontslagregeling geeft ook geen aanknopingspunten. Deze vraag moet aldus worden beantwoord op basis van de algemene redelijkheidsnorm die voor het arbeidsrecht is verankerd in het goed werkgever- en werknemerschap van artikel 7:611 BW.

In het goed werkgeverschap ligt onzes inziens besloten dat van een goed werkgever mag worden verwacht dat hij een werknemer probeert te herplaatsen op de functie die voor een werknemer het meest passend is. Anderzijds brengt de vrijheid van ondernemerschap met zich dat een werkgever zo veel mogelijk de vrijheid moet krijgen om zijn organisatie naar eigen wens en inzicht in te richten. Dit kan met zich brengen dat een werknemer in sommige gevallen met een 'minder passende maar toch passende' functie genoegen moet nemen indien de werkgever hiervoor overtuigende argumenten heeft. Een voorbeeld ter illustratie:

Lisa woont in Amsterdam en werkt bij bedrijf $\mathrm{X}$ als salesmedewerker op de bedrijfsvestiging in Haarlem. Lisa heeft een arbeidsovereenkomst voor onbepaalde tijd. De vestiging in Haarlem wordt gesloten, als gevolg waarvan Lisa zal worden ontslagen. Bedrijf X heeft nog twee vestigingen, een in Amsterdam en een in Rotterdam. Bij beide vestigingen wordt de positie van salesmedewerker opgevuld door een werknemer met een arbeidsovereenkomst voor bepaalde tijd. De twee posities zullen beide beschikbaar komen binnen een redelijke termijn. De werkgever biedt Lisa de positie van salesmedewerker in Rotterdam aan. Lisa wil echter liever naar Amsterdam. Op de positie in Amsterdam zit op dat moment Geert, die beduidend betere omzetcijfers haalt dan Lisa. Lisa geeft aan dat zij herplaatst wil worden op de positie in Amsterdam. De werkgever weigert echter Lisa de plek aan te bieden, omdat hij voornemens is om Geert een vaste aanstelling aan te bieden.

Deze casus illustreert hoe het ondernemersbelang van de werkgever en het werknemersbelang soms lijnrecht tegenover elkaar kunnen staan. Wij menen dat de werkgever in dit voorbeeld moet kunnen besluiten om Lisa de passende functie in Rotterdam aan te bieden, nu hij met Geert een aantoonbaar betere kandidaat heeft voor de arbeidsplaats in Amsterdam. De herplaatsingsplicht gaat in onze optiek niet zover dat de Lisa in dit voorbeeld herplaatsing in de voor haar meest gunstige passende functie kan afdwingen. De herplaatsingsplicht blijft een inspanningsverplichting van een werkgever. Dit betekent dat in het geval van meerdere passende functies geen afdwingbaar recht van een werknemer bestaat om op de meest passende functie te worden herplaatst. Wanneer de werkgever echter niet met overtuigende argumenten kan aantonen waarom hij in dit geval 
voor Geert kiest, brengt het goed werkgeverschap met zich dat hij Lisa, met een gelijkwaardig trackrecord en een arbeidsovereenkomst voor onbepaalde tijd, in de voor haar meest passende functie herplaatst.

Concluderend menen wij dat bij meerdere passende functies de ondernemersvrijheid vooropstaat. Deze wordt echter begrensd door het goed werkgeverschap, zodat het aanbieden van een passende functie met bijvoorbeeld een grote reisafstand terwijl op de eigen locatie van de werknemer ook een passende functie voorhanden is, zonder goede motivering toch in strijd met de herplaatsingsplicht kan zijn.

\section{Scholingsplicht}

Wanneer sprake is van een voldragen ontslaggrond zal de werkgever (behoudens de e-grond), voordat hij tot opzegging of ontbinding van de arbeidsovereenkomst overgaat, moeten onderzoeken of herplaatsing van de werknemer, al dan niet met behulp van scholing, mogelijk is. De Ontslagregeling geeft in artikel 10 weliswaar nadere invulling aan de redelijke termijn om werknemers al dan niet met behulp van scholing te herplaatsen - deze is gelijk is aan de opzegtermijn die voor de werkgever geldt ${ }^{31}$ - maar er wordt geen duidelijke specificering gegeven van de inspanningen die redelijkerwijs van een werkgever kunnen worden verlangd om de werknemer scholing aan te bieden. In deze paragraaf onderzoeken wij zowel de reikwijdte van de scholingsplicht als de vraag wie opdraait voor de scholingskosten.

\subsection{Hoe ver reikt de scholingsplicht?}

$\mathrm{Nu}$ de scholingsverplichting in het kader van herplaatsing nergens nader is geconcretiseerd, dient in onze optiek ook ten aanzien hiervan aansluiting te worden gezocht bij het goed werkgeverschap van artikel 7:611 BW. Van een werkgever mag worden verwacht dat hij die scholing aanbiedt waartoe hij als goed werkgever gehouden is om daarmee een werknemer voor de organisatie in een andere functie te behouden. In de parlementaire geschiedenis valt terug te vinden dat deze inspanning in beginsel beperkt kan blijven tot het aanbieden van een kortdurende opleiding. ${ }^{32}$ Zo werd een cursus 'feedback geven en ontvangen' voor een disfunctionerende werknemer als voldoende zorg voor scholing van de werknemer gezien door Hof Arnhem-Leeuwarden. ${ }^{33}$ De gedachte rijst hierbij of de omvang van de scholingsplicht wordt beinvloed door de mate waarin de werkgever tijdens een verbetertraject reeds heeft geïvesteerd in scholing en opleiding van de werknemer. Wat ons betreft zou hierbij onderscheid moeten worden gemaakt in het type scholing dat is aangeboden. Wanneer dit om vakinhoudelijke scholing voor de eigen

31. Behalve bij arbeidsgehandicapten, daar bedraagt de herplaatsingstermijn altijd zes maanden.

32. Kamerstukken I/ 2013/14, 33818, 3, p. 43.

33. Hof Arnhem-Leeuwarden 24 oktober 2017, ECLI:NL:GHARL: 2017:9489. functie van de werknemer gaat, is het meenemen van de betreffende scholing in het kader van de scholingsplicht bij herplaatsing niet goed voorstelbaar. Het gaat bij de scholing bij herplaatsing immers om scholing naar een passende functie. Eerder aangeboden scholing in de eigen functie van de werknemer behoort hier niet toe en zou in onze optiek dus niet kunnen meewegen bij de vraag of een werkgever voldoende aan (om)scholing heeft gedaan. Dit ligt anders bij scholing die op de persoon van de werknemer ziet, zoals coaching in gedrag, communicatie en omgangsvormen, wanneer deze voorwaarden ook in de passende functie worden vereist. Wanneer de werkgever in deze vaardigheden gedurende het verbetertraject al voldoende heeft geïnvesteerd en deze vaardigheden 'onvoldoende ontwikkelbaar' zijn gebleken, dan behoeft in het kader van de scholing bij herplaatsing niet opnieuw in de ontwikkeling van deze vaardigheden energie te worden gestoken. ${ }^{34}$

Scholing kan alleen van een (goed) werkgever gevergd worden wanneer door middel van scholing zicht is op eventuele herplaatsing in een passende functie. Indien geen concreet zicht bestaat op herplaatsing van de medewerker in een passende functie is de werkgever dus niet verplicht om een werknemer scholing aan te bieden. ${ }^{35}$

Wellicht kan voor de invulling van de scholingsplicht ook aansluiting worden gezocht bij het met de Wwz geïntroduceerde artikel 7:611a BW. ${ }^{36}$

Deze bepaling stelt immers dat scholing ook moet worden aangeboden voor de situatie waarin de functie van de werknemer komt te vervallen of de werknemer niet langer in staat is zijn functie te vervullen. Deze bepaling sluit hiermee aan op de regel uit artikel 7:669 lid 1 BW dat de arbeidsovereenkomst in beginsel alleen kan worden beëindigd als herplaatsing van de werknemer in een andere functie, al dan niet met behulp van scholing, niet mogelijk is of niet in de rede ligt. De scholing in het kader van de herplaatsing is echter beperkter en hoeft enkel gericht zijn op het passend maken van een concrete functie voor de werknemer. Scholing ten behoeve van een bredere inzetbaarheid op de arbeidsmarkt valt hier dus niet onder. ${ }^{37}$ Hiermee is de scholing van artikel 7:669 lid $1 \mathrm{BW}$ beperkter in omvang dan in artikel 7:611a BW het geval is.

Het gevolg hiervan is overigens dat investeringen in scholing in het kader van herplaatsing daarom niet in aanmerking komen voor verrekening met de transitievergoeding omdat deze zijn gericht op het behoud van de arbeidsovereenkomst (zie art. 3 Besluit voorwaarden in mindering brengen kosten op transitievergoeding).

34. Zie in gelijke zin Ktr. Arnhem 19 december 2016, ECLI:NL:RBGEL: 2016:7119, AR-Updates 2016-1471.

35. Zie ook Rechtbank Midden-Nederland 18 maart 2016, ECLI:NL: RBMNE:2016:1425.

36. Zie hierover ook D.J.B. de Wolff, 'De scholingsplicht van de werkgever', TRA 2015/24.

37. Hof Arnhem-Leeuwarden oordeelde al dat herplaatsing in het 'tweede spoor' niet van de werkgever kan worden verlangd (Hof Arnhem-Leeuwarden 25 april 2016, ECLI:NL:GHARL:2016:3301). 
De concrete vraag waartoe een goed werkgever is gehouden bij het aanbieden van scholing hangt af van de concrete omstandigheden van het geval. Hierbij dienen in onze optiek de volgende omstandigheden te worden betrokken:

- de duur van de scholing;

- de kosten van de scholing;

- de financiële draagkracht van de werkgever; 38

- de duur van het dienstverband van de werknemer;

- de leeftijd van de werknemer;

- de mate van scholingsinspanningen gedurende het dienstverband.

De weging van bovenstaande factoren kan in een concrete situatie per werkgever verschillen in uitkomst wat in het kader van scholing mag worden verwacht. Wellicht dat van een werkgever meer scholingsinspanningen mogen worden verwacht wanneer tijdens het dienstverband (vrijwel) niets aan scholing is gedaan. Hiermee komen artikel 7:611a BW en de scholingsplicht van artikel 7:669 lid 1 BW feitelijk in elkaars verlengde te liggen. Tot op heden bestaat echter geen rechtspraak die deze veronderstelling bevestigt of ontkracht.

\subsection{Wie draagt de scholingskosten?}

Ten aanzien van de vraag wie opdraait voor de scholingskosten heeft de wetgever evenmin duidelijkheid gecreëerd. Wel is hierover bij de behandeling in de Eerste Kamer een toelichting gegeven. De minister geeft aan dat het gaat om investeringen van de werkgever en dat de werkgever daarom in beginsel is gehouden de kosten te betalen van functiegerichte scholing en scholing gericht op een andere functie in het bedrijf als de eigen functie niet langer kan worden vervuld. ${ }^{39} \mathrm{Uit}$ de wetsgeschiedenis valt echter niet af te leiden of is bedoeld de werkgever in alle gevallen voor alle kosten te laten opdraaien, alsmede de werknemer in staat te stellen de scholing fulltime in werktijd te volgen. In onze optiek komt ook deze vraag uiteindelijk neer op een invulling van het goed werkgever- en werknemerschap. Het zal daarbij dus afhangen van de omstandigheden van het geval wat 'redelijk' is als het aankomt op de scholingsplicht van de werkgever. De hiervoor genoemde omstandigheden kunnen daarbij eveneens als leidraad gelden.

In onze optiek moet een onderscheid worden gemaakt bij het aanbieden van korte cursussen en trainingen met geringe kosten - deze zullen doorgaans volledig voor

38. In de toelichting op art. 9 Ontslagregeling staat verwoord dat de financiële positie van de werkgever als omstandigheid moet worden meegewogen bij het bepalen van de mate van scholingsinspanningen die van de werkgever kunnen worden gevergd. Wel weegt Hof Arnhem in een pre-Wwz-uitspraak de financiële situatie van de werkgever mee bij het bepalen of scholing al dan niet kan worden gevergd (Hof Arnhem 2 oktober 2012, ECLI:NL:GHARN:2012:BX8873. Deze uitspraak dateert weliswaar van vóór de Wwz, maar ook voor de Wwz bestond er uit hoofde van goed werkgeverschap al de verplichting om scholing aan te bieden wanneer daarmee een passende functie kon worden gerealiseerd, voor zover de omscholing van de werkgever als goed werkgever viel te verlangen).

39. Kamerstukken I 2013/14, 33818, C. rekening van de werkgever komen - en langdurige, dure opleidingen of studies waarbij de herplaatsingstermijn zoals genoemd in artikel 10 Ontslagregeling wordt overschreden. In die laatste situatie lijkt het niet meer dan redelijk om de werknemer ook zelf een deel van de kosten te laten dragen. Wanneer de scholing binnen de redelijke termijn als bedoeld in artikel 10 Ontslagregeling kan worden volbracht en de werknemer weigert deze scholing te volgen, waarna ontslag als enige mogelijkheid resteert, dan zou zelfs kunnen worden betoogd dat de werknemer hiermee ernstig verwijtbaar handelt. De werknemer had immers binnen de in de Ontslagregeling gestelde kaders voor baanbehoud kunnen opteren. Wij zien niet in waarom dergelijk weigerachtig gedrag van de werknemer zou moeten worden beloond met een transitievergoeding. Dit ligt anders bij aangeboden scholing die de maximale termijn uit artikel 10 Ontslagregeling overschrijdt of waarvoor de werknemer zelf deels de kosten zou moeten betalen. Het niet accepteren van deze (om)scholing is naar onze mening niet als ernstig verwijtbaar te kwalificeren nu dit aanbod buiten de reikwijdte van de Ontslagregeling valt. Wij menen dat hetgeen in redelijkheid van een goed werknemer kan worden gevergd, wordt begrensd door hetgeen de Ontslagregeling voorschrijft. Tot op heden is hierover nog geen rechtspraak verschenen.

Wanneer de werknemer gedurende het volgen van scholing alvast in de nieuwe functie is geplaatst, maar de definitieve plaatsing afhankelijk is gemaakt van het succesvol afronden van de scholing (de zogenoemde tijdelijke of proefplaatsing) en de scholing vervolgens niet succesvol wordt afgerond, kan geen definitieve plaatsing volgen. In die situatie is herplaatsing in een passende functie niet mogelijk gebleken, omdat de functie niet als passend kwalificeert nu de werknemer niet over de vereiste capaciteiten blijkt te beschikken. De werkgever kan dan aantonen dat hij zijn inspanningsplicht op het gebied van herplaatsing heeft vervuld en vervolgens alsnog tot een ontslagprocedure overgaan.

Tot slot merken wij op dat de werkgever bij het aanbieden van een opleiding een studiekostenbeding met de werknemer kan overeenkomen, waarin is geregeld dat de werknemer bij vrijwillige opzegging (een deel van) de studiekosten of het loon over opleidingsuren terugbetaalt. De werkgever kan daarmee bij een vertrek van de werknemer nog wel (een deel van) de scholingskosten op de werknemer verhalen.

\section{Herplaatsing in concernverband in binnen- en buitenland}

Met de invoering van de Wwz en daarmee de verankering van de herplaatsingsplicht in het $\mathrm{BW}$ is door de wetgever geen inhoudelijke wijziging beoogd, zo blijkt 
uit de parlementaire geschiedenis. ${ }^{40}$ In de literatuur zijn echter reeds door verschillende auteurs vraagtekens bij deze uitlating geplaatst. ${ }^{41}$ Met name de herplaatsingsverplichting in concernverband zoals verwoord in artikel 9 lid 2 Ontslagregeling lijkt een verdergaande strekking te hebben dan de herplaatsingsplicht zoals deze voor de Wwz gold. In artikel 9 lid 2 Ontslagregeling is bepaald dat wanneer de werkgever onderdeel uitmaakt van een groep, in het kader van de herplaatsingsverplichting ook arbeidsplaatsen bij andere tot de groep behorende ondernemingen moeten worden betrokken. Dit lijkt op een nieuwe en verregaande verplichting van de werkgever te duiden. In deze paragraaf bespreken wij een aantal praktische vragen die samenhangen met deze herplaatsing in concernverband.

5.1 Wat is een 'groep' in de zin van artikel 9 lid 2 Ontslagregeling en behoren hiertoe ook buitenlandse vennootschappen?

De herplaatsingsverplichting van de werkgever is in artikel 9 lid 2 Ontslagregeling uitgestrekt tot de groep waartoe de onderneming van de werkgever behoort. Voor de definitie van een 'groep' wordt vervolgens aansluiting gezocht bij artikel 2:24b BW. In dit artikel is bepaald dat onder een groep wordt verstaan 'een economische eenheid waarin rechtspersonen en vennootschappen organisatorisch zijn verbonden'. De definitie van 'groep' wordt in de praktijk ruim uitgelegd. Vrijwel iedere verwevenheid tussen vennootschappen en/of andere rechtspersonen wordt aangemerkt als groep in de zin van artikel 2:24b BW. Dit betekent doorgaans dat het gehele concern moet worden betrokken in de toets of aan de herplaatsingsverplichting is voldaan. De definitie in artikel 2:24b BW en de hieraan gekoppelde herplaatsingsplicht van artikel 9 lid 2 Ontslagregeling is niet beperkt tot de Nederlandse landsgrens. In principe is de werkgever verplicht om ook herplaatsing te onderzoeken bij de buitenlandse vennootschappen die tot het concern behoren.

Het verdient aanbeveling om in iedere ontslagzaak eerst de vennootschapsrechtelijke structuur van de werkgever in kaart te brengen, om zodoende de werkgever concreet te vragen naar herplaatsingsmogelijkheden binnen alle vennootschappen die onderdeel van het concern uitmaken. Gelet op de harde voorwaarde die herplaatsing vormt alvorens tot ontslag te mogen overgaan, kan deze informatie ook van invloed zijn op de te voeren onderhandelingsstrategie.

\subsection{Geldt de herplaatsingsplicht binnen} concernverband ook voor de flexibele schil?

Een van de vragen die rijst in het kader van de herplaatsingsverplichting binnen concernverband is die naar de

40. Kamerstukken // 2013/14, 33818, 3, p. 43 en 98 en Handelingen II 2013/14, 33818, 54, item 9, p. 20.

41. Zie o.a. L.B. de Graaf, 'Herplaatsing: waar is de redelijkheid gebleven?' TRA 2016/82; F.G. Laagland en I. Lintsen, 'Werkgeverschap in concernverhoudingen', TRA 2016/13; R. Olivier en J.P. Wiewel, 'Herplaatsing binnen de groep', TAP 2017/2, p. 4-10 en R.M. Beltzer en S. Schmeetz, 'Herplaatsing binnen het concern', TVO 2017/2, p. 64-74. reikwijdte. In artikel 9 lid 1 Ontslagregeling wordt bij de herplaatsingsverplichting onderscheid gemaakt in een tweetal categorieën functies waarop moet worden herplaatst: (a) vacatures en (b) flexibele schil. De vraag is of de verplichting tot herplaatsing in concernverband zich uitstrekt tot zowel (a) als (b). Zowel Laagland en Lintsen als Beltzer en Schmeetz bepleiten dat de herplaatsingsverplichting in concernverband niet verder zou moeten strekken dan enkel openstaande vacatures. Het zou in strijd zijn met de ondernemersvrijheid wanneer een ondernemer van een andere vennootschap zou kunnen worden verplicht de flexibele schil af te bouwen ten faveure van een vaste medewerker die toevallig boventallig is of onvoldoende functioneert bij een andere vennootschap behorende tot de groep. ${ }^{42} \mathrm{Zij}$ zoeken hierbij steun in de nota van toelichting. ${ }^{43}$ Hoewel wij een beperkte uitleg van de herplaatsingsverplichting in concernverband wenselijk achten, vinden wij hiervoor onvoldoende steun in de inhoud van de Ontslagregeling. In artikel 9 lid 2 Ontslagregeling wordt immers geen beperking tot enkel onderdeel a van artikel 9 lid 1 Ontslagregeling gemaakt. Weliswaar staat in de nota van toelichting enkel bij de toelichting op onderdeel a van artikel 9 lid 1 Ontslagregeling expliciet dat deze ook van toepassing is op vacatures binnen het concern en ontbreekt deze specifieke verwijzing bij de toelichting op onderdeel b, maar bij de toelichting op onderdeel b staat evenmin dat de genoemde verplichting niet binnen concern zou moeten worden toegepast. $\mathrm{Nu}$ de wetsgeschiedenis over de herplaatsingsplicht wel meer tegenstrijdigheden omvat - verwezen wordt o.a. naar de opmerking van de minister dat geen wijzigingen ten opzichte van het pre-Wwz-tijdperk is beoogd ${ }^{44}-$ zijn wij met Olivier en Wiewel van mening dat aan de parlementaire geschiedenis in dit verband niet te veel waarde moet worden gehecht. ${ }^{45}$ Leidend zou onzes inziens moeten zijn de tekst van de Ontslagregeling. Nu de tekst van artikel 9 lid 2 Ontslagregeling geen onderscheid maakt in de categorie a- en b-functies van artikel 9 lid 1 Ontslagregeling moet hieruit volgens ons de conclusie worden getrokken dat ook de door flexibele arbeidskrachten vervulde functies binnen het concern in de herplaatsingsverplichting dienen te worden betrokken, hoe onwenselijk deze uitkomst wellicht ook moge zijn. Het is aan de wetgever om - wanneer hij dit anders ingevuld wenst te zien - dienaangaande met een aanpassing van de Ontslagregeling te komen, bijvoorbeeld een beperking tot enkel onderdeel a van artikel 9 lid 1 Ontslagregeling.

42. F.G. Laagland en I. Lintsen, 'Werkgeverschap in concernverhoudingen', TRA 2016/13 en R.M. Beltzer en S. Schmeetz, 'Herplaatsing binnen het concern', TVO 2017/2, p. 66.

43. Nota van toelichting, Stcrt. 2015,12685 , p. $15-16$

44. Handelingen II, 2013/14, 33818, 54, item 9, p. 20 vs. nota van toelichting, Stcrt. 2015, 12685, p. 15-16.

45. R. Olivier en J.P. Wiewel, 'Herplaatsing binnen de groep', TAP 2017/2, p. 6. Zie ook de Hoge Raad in de Mediant-beschikking (HR 23 december 2016, ECLI:NL:HR:2016:2998, JAR 2017/19, r.o. 3.17.2). 


\subsection{Kun je als werknemer herplaatsing bij een} andere vennootschap afdwingen?

Een vraag die met het voorgaande samenhangt, is de mate van afdwingbaarheid van herplaatsing door de werknemer. Wij merken dat in de dagelijkse praktijk nogal eens dezelfde misvatting heerst. De in artikel 7:669 lid 1 jo. artikel 9 Ontslagregeling beschreven herplaatsingsverplichting is zodanig geformuleerd dat het een voorwaarde is voor de contractuele werkgever waaraan moet worden voldaan alvorens tot ontslag mag worden overgegaan. Net zoals moet kunnen worden aangetoond dat correct is afgespiegeld (a-grond) of dat een voldoende verbetertraject moet zijn doorlopen (d-grond) is de herplaatsingsverplichting voor de werkgever niet meer of minder dan een horde die moet worden genomen om uiteindelijk tot ontslag van de betreffende werknemer over te gaan. Nergens in de wet of in de Ontslagregeling is voor de werknemer een 'recht op herplaatsing' neergelegd. Dit betekent dat een werknemer die van mening is dat de werkgever onvoldoende aan zijn herplaatsingsverplichting heeft voldaan, enkel een afwijzing van het ontbindings- of toestemmingsverzoek kan realiseren. Het rechtsgevolg hiervan is dat de werkgever de betreffende werknemer niet mag ontslaan en dus in dienst moet houden en loon moet blijven betalen. Afdwingbaarheid van herplaatsing door de werknemer is niet aan de orde, omdat de wet hiervoor geen basis biedt. Wij zijn daarbij de mening toegedaan dat de inspanningsverplichting van de werkgever verder gaat dan enkel binnen het concern navraag doen of een ander concernonderdeel de betreffende werknemer wil herplaatsen. In de tekst van artikel 7:669 lid $1 \mathrm{BW}$ staat immers 'dat herplaatsing (...) niet mogelijk is' gedefinieerd als voorwaarde voor de werkgever om succesvol een ontslag gerealiseerd te krijgen. Wanneer herplaatsingsmogelijkheden binnen de groep bestaan en de andere concernonderdelen weigeren de werknemer te herplaatsen, dan is onze conclusie dat herplaatsing dus theoretisch gezien wel mogelijk is en daarmee niet aan de wettelijke voorwaarde voor ontslag is voldaan. De tegenovergestelde opvatting, namelijk dat herplaatsing enkel een inspanningsverplichting inhoudt en dat een 'nee' binnen de groep al voldoende is om an die inspanningsverplichting te voldoen, zou tot de conclusie leiden dat feitelijk sprake is van een loze verplichting tot herplaatsing in concernverband. Ter illustratie een voorbeeld.

Stel Esther is telefonist bij BV A. Zij is boventallig, want op grond van het afspiegelingsbeginsel komt Esther voor ontslag in aanmerking. Esther constateert dat binnen het concern bij BV B nog een uitzendkracht als telefonist werkzaam is en dat bij BV C een vacature als telefonist openstaat. BV B en BV C hebben echter te kennen gegeven dat zij Esther niet zien zitten. In de ontslagprocedure bij het UWV voert Esther aan dat er binnen concernverband herplaatsingsmogelijkheden zijn. Op basis hiervan concludeert het UWV dat het verzoek om een ontslagvergunning dient te worden afgewezen. Esther wendt zich vervolgens tot $\mathrm{BV}$ A met de sommatie tot herplaatsing bij BV B of BV C. Deze vennootschappen volharden echter in hun weigering Esther te herplaatsen.

Esther kan in deze concrete casus geen herplaatsing bij BV B of BV C afdwingen. Zij behoudt dankzij de weigering van een ontslagvergunning door het UWV haar arbeidsovereenkomst met BV A, alsmede haar recht op loon van BV A. Het niet kunnen herplaatsen van Esther door BV A bij BV B of BV C komt immers voor rekening en risico van $\mathrm{BV}$ A. Nu BV A zelf geen werk meer heeft voor Esther - haar functie is immers komen te vervallen - ontstaat de vreemde patstelling dat BV A geen werk heeft, maar wel loon moet betalen en niet tot ontslag kan overgaan - terwijl Esther evenmin tewerkstelling kan afdwingen. BV A heeft geen werk en met BV B en BV C heeft zij geen contractuele relatie, zodat haar de mogelijkheden van Boek 7.10 BW niet ter beschikking staan tegen deze vennootschappen. In deze situatie kan BV A een tweetal oplossingen forceren: ofwel alsnog $\mathrm{BV}$ B of BV C bewegen om Esther te herplaatsen, ofwel in onderling overleg tot beëindiging van de arbeidsovereenkomst met Esther komen. Dit laatste zal dan waarschijnlijk wel substantieel meer gaan kosten dan de transitievergoeding, nu Esther een sterke onderhandelingspositie heeft.

Voorgaande casus illustreert hoe de herplaatsingsverplichting in concernverband in de praktijk uitvoering krijgt. De casus illustreert tevens dat de door Laagland en Lintsen, alsmede Beltzer en Schmeetz geuite bezwaren over inperking van de ondernemersvrijheid in de praktijk niet aan de orde zijn. Immers, in het voorbeeld kunnen BV B en BV C juridisch niet worden verplicht om Esther een arbeidsovereenkomst aan te bieden. $\mathrm{Zij}$ kunnen blijven weigeren, bijvoorbeeld omdat zij een andere kandidaat prefereren. Enkel BV A wordt hiermee met een probleem opgezadeld, omdat geen ontslag kan worden gerealiseerd zonder instemming van Esther. Dit is weliswaar lastig (en wellicht zelfs onwenselijk), maar wij zien niet hoe de ondernemersvrijheid hiermee zou worden aangetast. Ook het bezwaar van het uitstrekken van de herplaatsingsplicht tot buitenlandse vennootschappen wordt hiermee feitelijk weggenomen. Buitenlandse vennootschappen kunnen namelijk niet worden verplicht een werknemer van een Nederlandse 'groepsgenoot' te herplaatsen. Wel moeten herplaatsingsmogelijkheden in het buitenland door de Nederlandse werkgever worden onderzocht alvorens te voldoen aan de in artikel 7:669 lid 1 BW jo. artikel 9 lid 2 Ontslagregeling neergelegde herplaatsingsplicht.

\subsection{Kun je een arbeidsovereenkomst voor bepaalde tijd krijgen?}

Wanneer een werknemer uiteindelijk kan worden herplaatst bij een andere vennootschap binnen het concern, rijst de vraag welke gevolgen dit heeft voor de arbeidsovereenkomst. Mag de nieuwe werkgever binnen het 
concern bijvoorbeeld een arbeidsovereenkomst voor bepaalde tijd aanbieden? Zoals Beltzer en Schmeetz terecht aangeven, hangt een en ander samen met de problematiek van opvolgend werkgeverschap. ${ }^{46}$ Uitgangspunt is dat de nieuwe werkgever binnen het concern aan de werknemer een arbeidsovereenkomst mag aanbieden die hij wenst. Wanneer echter sprake is van opvolgend werkgeverschap kan dit invloed hebben op de duur van de overeenkomst. Op grond van artikel 7:668a lid 2 BW converteert een arbeidsovereenkomst voor bepaalde tijd direct naar een arbeidsovereenkomst voor onbepaalde tijd indien de werknemer reeds een arbeidsovereenkomst voor onbepaalde tijd had bij de oude werkgever die minimaal 24 maanden heeft geduurd.

Met invoering van de Wwz is sprake van opvolgend werkgeverschap wanneer de werknemer soortgelijke werkzaamheden op soortgelijke wijze blijft uitvoeren. Of daarnaast sprake is van 'zodanige banden' tussen de oude en de nieuwe werkgever binnen het concern is niet (langer) relevant. ${ }^{47}$ Wanneer de werknemer ongeveer dezelfde werkzaamheden blijft verrichten, behoudt hij daarmee niet alleen zijn 'onbepaaldetijdstatus', maar blijven ook de anciënniteit in het kader van de opzegtermijn van artikel 7:672 BW en de transitievergoeding van artikel 7:673 lid 4 BW behouden.

Om te voorkomen dat sprake is van opvolgend werkgeverschap kan een werknemer simpelweg een functie worden aangeboden die afwijkt qua werkzaamheden en uitvoering. In het kader van wat als passende functie wordt aangemerkt, kan breed worden gezocht naar alle functies die aansluiten bij opleiding, ervaring en capaciteiten van de werknemer. Niet uitgesloten is dat werkgevers voorafgaand aan een ontslagtraject aan een werknemer een functie aanbieden bij een andere concernvennootschap die wezenlijk andere vaardigheden vraagt dan de oude functie. Vervolgens kan met een arbeidsovereenkomst voor bepaalde tijd zonder behoud van anciënniteit afscheid worden genomen door eenvoudigweg de arbeidsovereenkomst voor bepaalde tijd niet te verlengen. Met strategisch gebruik kan de herplaatsingsplicht daarmee juist een tool voor de werkgever opleveren in het ontslagtraject. Wanneer de werknemer de aan hem aangeboden passende functie weigert, heeft hij immers niet alleen een mogelijk verweer in de ontslagprocedure prijsgegeven, maar is daarnaast ook het risico van artikel 24 lid $3 \mathrm{WW}$ reëel aanwezig. Voor de werknemer rest doorgaans dus geen andere mogelijkheid dan de aangeboden arbeidsovereenkomst voor bepaalde tijd te accepteren, tenzij dit aanbod buiten de kaders van de Besluit passende arbeid WW en ZW valt, conform hetgeen wij bespraken in $\$ 3.2 .1$ van dit artikel.

46. R.M. Beltzer en S. Schmeetz, 'Herplaatsing binnen het concern', TVO 2017/2, p. 66-67.

47. Het criterium zoals door de Hoge Raad geformuleerd in het Van Tuinen-arrest (HR 11 mei 2012, ECLI:NL:HR:2012:BV9603, JAR 2015/150) is met invoering van de Wwz komen te vervallen.
5.5 Kun je een proeftijd krijgen bij herplaatsing in een andere functie?

Bij het aanbieden van een nieuwe arbeidsovereenkomst door een andere vennootschap binnen het concern bestaat de mogelijkheid om een proeftijd overeen te komen. Deze situatie wordt beheerst door artikel 7:652 lid 8 onder e BW, welke bepaling ziet op het opnemen van een proeftijd bij een andere werkgever. Hierbij moet onderscheid worden gemaakt tussen twee gevallen:

1. De werknemer blijft dezelfde werkzaamheden vervullen; in dit geval is van belang of de nieuwe werkgever ten opzichte van de oude werkgever kan worden aangemerkt als 'opvolgend werkgever'. Anders dan bij de ketenregeling of de transitievergoeding is in dit verband nog steeds van belang het criterium als verwoord door de Hoge Raad in het arrest Slijkoord/Hekkema. ${ }^{48}$ Getoetst wordt niet alleen of inderdaad soortgelijke werkzaamheden worden vervuld, maar daarnaast of sprake is van 'zodanige banden' tussen de oude en de nieuwe werkgever dat zij redelijkerwijs als elkaars opvolger kunnen worden beschouwd. Binnen concernverband zal hieraan misschien snel worden voldaan, maar bij ingewikkelde vennootschapsrechtelijke structuren kan dit wellicht anders zijn.

2. De werknemer gaat andere werkzaamheden vervullen; wanneer de veranderde werkzaamheden wezenlijk andere vaardigheden of verantwoordelijkheden vergen, mag - ook wanneer sprake is van opvolgend werkgeverschap - een proeftijd worden opgenomen in de nieuwe arbeidsovereenkomst. Dit is overigens niet anders dan herplaatsing bij de eigen werkgever (art. 7:652 lid 8 onder d BW).

\section{Conclusie}

In deze bijdrage hebben wij de reikwijdte van de herplaatsingsplicht onderzocht aan de hand van een aantal in de praktijk veel voorkomende vraagstukken. Uit ons onderzoek is gebleken dat - anders dan de minister heeft betoogd - een uitbreiding van verplichtingen van de werkgever heeft plaatsgevonden. Hoewel de herplaatsingsverplichting 'slechts' een inspanningsverplichting is, brengt de mate van de door de werkgever te leveren inspanning met zich dat in de praktijk serieus rekenschap moet worden gegeven van de herplaatsingsplicht alvorens tot een ontslag te kunnen komen. De herplaatsingsinspanning is immers als constitutief vereiste voor vrijwel ieder ontslag in de wet verankerd. Vooralsnog zien we echter nog weinig jurisprudentie waarin de herplaatsingsplicht onderwerp van discussie is. Wanneer werknemers(advocaten) zich (nog) meer bewust zijn van hetgeen van de werkgever wordt gevraagd ten aanzien van de aan te bieden vacatures, afbouwen van flexibele schil, aan te bieden scholing en dat ook nog eens in con-

48. HR 24 oktober 1986, ECLI:NL:HR:1986:AC9537, NJ 1987, 293 (Slijkoord/Hekkema). 
cernverband, en hier in de ontslagpraktijk meer nadruk op gaan leggen, zal dat naar onze mening tot een (verdere) daling van het antal succesvolle ontslagprocedures leiden. 